\title{
Wind farm potential is higher in prime habitat for uncommon soil crust lichens
}

Heather T Root ${ }^{1,3^{*}}$, Myrica McCune ${ }^{2}$ and Bruce McCune ${ }^{1}$

\begin{abstract}
Introduction: Biotic soil crust communities contribute valuable ecosystem services and biodiversity in steppe ecosystems. The uncommon crust lichens Acarospora schleicheri, Fuscopannaria cyanolepra, Rhizocarpon diploschistidina, and Texosporium sancti-jacobi are associated with fine-textured soils along rivers of the Columbia Basin. A. schleicheri and R. diploschistidina indicate late-successional habitat and may serve as indicators for other rare or cryptic species associated with similar habitats. Much of the most favorable habitat for these species has been lost to urban and agricultural development. We sought to overlay favorable habitats with wind farm development potential to assess whether these species are likely to be affected by renewable energy development.

Methods: We overlaid habitat models for four lichen species on land use and wind farm potential maps. Using a sample of 5,000 points, we determined whether there were differences in probability of occurrence among wind farm potential classes within developed and natural lands using Multi-Response Permutation Procedures. Sites with modeled probability of occurrence greater than $60 \%$ were considered "favorable" habitats; for these, a X2 test allowed us to determine whether favorable habitats were associated with wind farm potential categories.

Results: Sites that are developed for agriculture or have higher wind farm potential coincide with more favorable habitats for uncommon soil crust lichens. Of the favorable habitats for the four focal lichens, $28-42 \%$ are already affected by development or agriculture; 5-14\% of favorable habitats remain in natural vegetation and are considered sites with fair or good potential for wind farms.

Conclusions: Development of wind energy has the potential to negatively impact uncommon soil crust lichen species because favorable sites coincide with especially good habitat for these species. However, as these renewable energy resources are developed, we have the opportunity to ensure that valuable soil crust functions and diversity are maintained by surveying before construction and planning new facilities such that disturbance to existing habitat is minimized.
\end{abstract}

Keywords: Acarospora schleicheri, Agriculture, Biotic soil crust, Columbia river, Fuscopannaria cyanolepra, Land use, Rhizocarpon diploschistidina, Steppe, Texosporium sancti-jacobi

\section{Introduction}

Grasslands and sagebrush (Artemisia) steppe occupy large areas of central and eastern Oregon; on a large scale, this habitat appears abundant and homogeneous. However, upon closer examination, native flora and fauna differ substantially in association with subtle habitat differences (Crawford et al. 2004; Root and McCune

\footnotetext{
* Correspondence: ericarhiza@gmail.com

'Department of Botany and Plant Pathology, Oregon State University, 2082 Cordley Hall, Corvallis, OR 97330, USA

${ }^{3}$ Current address: Department of Forest Ecosystems and Society, Oregon

State University, 321 Richardson Hall, Corvallis, OR 97331, USA

Full list of author information is available at the end of the article
}

2012). Soils range from pumice and sand to silty loams and calcareous barrens, supporting at least 12 sagebrush taxa that differ in their palatability to wildlife (Rosentreter 2004). Rainfall ranges from 22 to $50 \mathrm{~cm} /$ year (Daly et al. 2008). Sites along the Columbia River have fairly low seasonal temperature variation, transitioning to a more continental climate at higher elevations. Land use patterns also differ across habitats: poorer sites often support ranches and livestock grazing, loamy sites and flat plateaus near rivers have largely been converted to agriculture, and urban areas and

\section{Springer}

(c) 2013 Root et al.; licensee Springer. This is an Open Access article distributed under the terms of the Creative Commons Attribution License (http://creativecommons.org/licenses/by/2.0), which permits unrestricted use, distribution, and reproduction in any medium, provided the original work is properly cited. 
towns along rivers are expanding into adjacent native steppe.

In the past decade, wind power generation has grown dramatically in the Pacific Northwest of North America, allowing western states cost-effective opportunities to meet their renewable energy goals. More than $80 \%$ of the regional wind development has occurred in the Columbia Basin, and regional energy plans call for increasing development of wind power each year through 2030 (NPCC 2010). Environmental conflicts have been minimized by siting projects on agricultural and grazing lands; however, wind farms are known to negatively impact bats and birds (Drewitt and Langston 2006; Baerwald and Barclay 2009), and their expansion onto wildlands could impact terrestrial native flora and fauna. Among native organisms likely to be affected by wind farm expansion is the biotic soil crust community, a rich association of lichens, bryophytes, algae, bacteria and fungi.

Biotic soil crust species are small and inconspicuous, but they efficiently stabilize soils in habitats prone to erosion and desertification (Harper and Marble 1988; Mazor et al. 1996; Leys and Eldridge 1998). Crusts can shape vascular plant communities by favoring establishment of some native over invasive species (Kaltenecker et al. 1999; Belnap et al. 2001; Mitchell et al. 2006). They also impact nutrient dynamics contributing biologically available nitrogen, carbon, and micronutrients (Rychert et al. 1978; Beymer and Klopatek 1991; Harper and Pendleton 1993; Belnap 2002). In addition to their functions as native ecosystem engineers (Jones et al. 1997), biotic soil crusts support a great diversity of lichens and bryophytes (Root et al. 2011).

Several uncommon species of soil crust lichens have been shown to associate with particular combinations of climate and soil types (Root et al. 2011). We focus on habitat associations and land use change risks for four uncommon lichens: (1) Acarospora schleicheri, a widespread yellow lichen that is reported to establish on Diploschistes muscorum (McCune and Rosentreter 2007), which itself frequently establishes on Cladonia (Friedl 1987) making A. schleicheri a late-successional species. (2) Fuscopannaria cyanolepra, a Pacific Northwest endemic that fixes nitrogen to a biologically active form. (3) Rhizocarpon diploschistidina, a recently discovered lichen (Lumbsch et al. 2011) similar in coloration and ecology to Acarospora schleicheri but growing obligately on Diploschistes muscorum. (4) Texosporium sancti-jacobi, a North American endemic with unusual fruiting bodies and spores (Tibell and van Hofsten 1968; McCune and Rosentreter 1992). This last species is federally listed by the U.S. Fish and Wildlife Service as a Species of Concern and is listed by the Natural Heritage Program as "Imperiled in Oregon" (ORBIC 2010a).
We overlay habitat favorability models developed in Root et al. (2011) for these four lichens with land use patterns to address two questions: (1) Do agriculture, development, and wind farms occur on sites that are otherwise particularly good habitats for these rare lichens? (2) What proportion of the habitat likely to support these rare lichens is either currently developed or at risk of development as wind farms expand?

\section{Methods}

We focused on steppe habitats of Oregon in the Prineville District boundary of the U.S. Department of Interior's Bureau of Land Management. Using ArcGIS (v 9.3.1 ESRI), we sampled plots on public lands within $3.2 \mathrm{~km}$ of a road stratified by USA-EPA Level IV Ecoregions (Clarke and Bryce 1997). We visited 59 plots in fall 2009 and spring 2010, surveying soil crust lichen community composition (Root et al. 2011). We supplemented this dataset with herbarium records and 21 intuitive plots targeting uncommon soil crusts and herbarium records (Figure 1). Uncommon lichens selected for modeling were fairly conspicuous and occurred frequently enough to be modeled; $A$. schleicheri, F. cyanolepra, $R$. diploschistidina, and $T$. sancti-jacobi were observed at $40,28,22$, and 28 sites.

For each species, we developed a model of lichen occurrence probability using soil characteristics including texture in the top $5 \mathrm{~cm}, \mathrm{pH}$, and bulk density (NRCS 2010) and synthetic climate variables (Root et al. 2011) derived from monthly precipitation and minimum and maximum temperatures modeled across the region with an 800-m resolution (PRISM, Daly et al. 2008). The synthetic climate variables were the first three axes of a principal component analysis. The first was most strongly associated with increasing temperature and decreasing precipitation, the second with decreasing minimum temperature and increasing maximum temperature, and the third with increasing winter maximum temperature and winter precipitation. The details of these models are not described here as they are well described elsewhere (Root et al. 2011).

Models of occurrence probability were fit using nonparametric multiplicative regression (NPMR; McCune 2006; McCune and Mefford 2011a). This is a multiplicative kernel smoother (Bowman and Azzalini 1997), a more flexible approach than the traditional logistic regression and a method that automatically models interactions among predictors (McCune 2006). We used a local mean estimator with a Gaussian kernel function. Model selection maximized the cross-validated loglikelihood ratio by finding the best combination of predictors and the smoothing parameter (tolerance) for each predictor. The minimum average neighborhood size for an acceptable model was set to 10 plots. We 


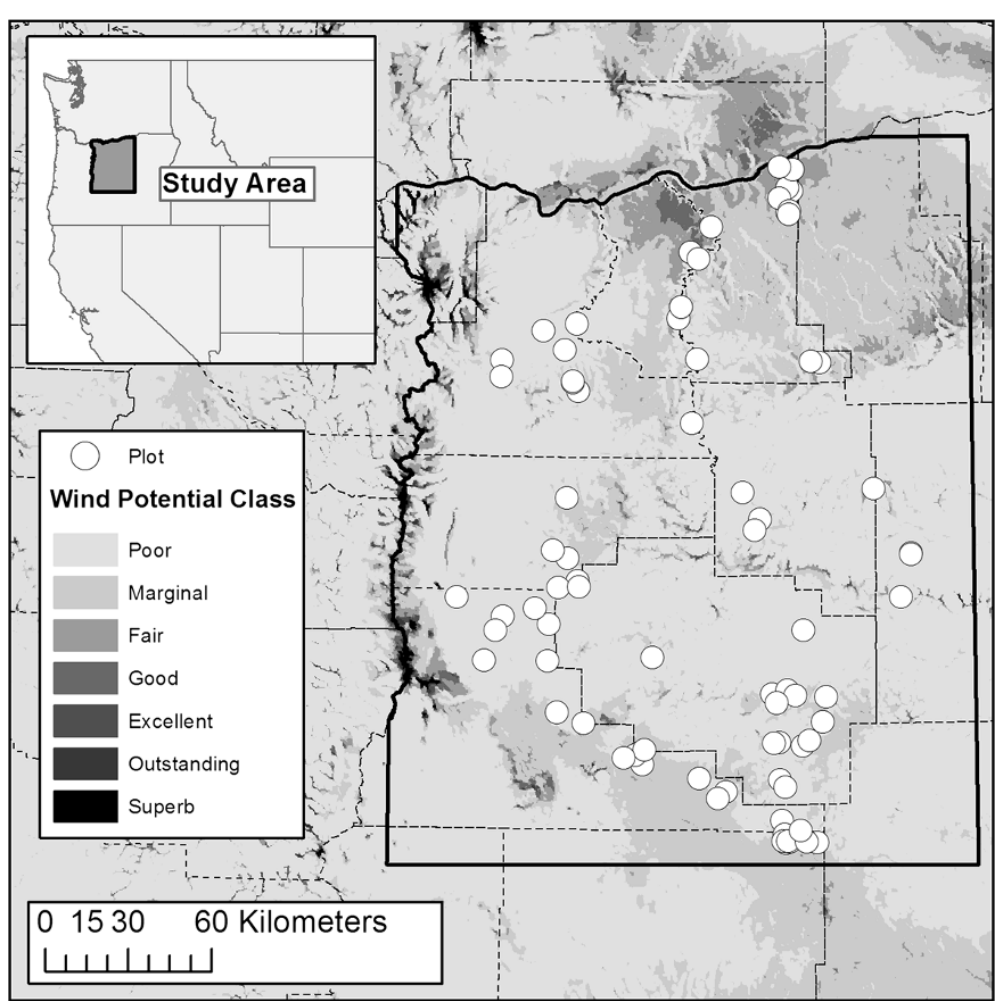

Figure 1 Map of study area. Wind farm potential and lichen plots surveyed for all four target species; excludes herbarium records for individual species. Dashed lines represent county boundaries.

evaluated model fits using the area under curve (AUC) for which 0.5 corresponds to random expectation and 1 to perfect fit and tested significance using a randomization test (see Root et al. 2011 for details of model selection).

Probabilities of occurrence were mapped across the region, excluding sites that were different enough from those sampled as to preclude predictions based on our models. We overlaid maps of land use (ORBIC 2010b) and wind farm potential categories poor, marginal, fair, and good (National Renewable Energy Laboratory 2002). To address our land use questions, we randomly sampled 5,000 points within a rectangle encompassing plots that we visited and calculated lichen occurrence probability, land use, and wind suitability for each point. We excluded points in barren and water areas.

Differences in probabilities of species occurrences among wind farm potential categories were compared with univariate permutation tests using Euclidean distance as implemented in procedure MRPP in PC-ORD (McCune and Mefford 2011b); although MRPP is often performed with multivariate data, it can also be used in the univariate context (Mielke and Berry 2001). Because the sample size was quite large and there were 48 pairwise comparisons, we chose a conservative $\alpha$-level of 0.001 for interpreting differences among land use categories. We then calculated the proportion of favorable lichen habitat (probability of occurrence exceeding $60 \%$ ) potentially affected by development, agriculture, or wind farm development. We used the cut off of $60 \%$ because using much higher values resulted in too few "favorable" sites to model and using much lower values became decreasingly biologically meaningful. Finally, we determined whether favorable habitats were associated with wind farm potential categories using contingency tables and a $\chi^{2}$ test.

\section{Results}

Each species' habitat model was unique; however, an overall pattern suggested that these uncommon lichens were associated with finer soils at sites with little annual temperature variability (Root et al. 2011). A. schleicheri was associated with warm, dry sites with little monthly temperature variation and low percent sand (AUC = $0.83, p=0.01) . F$. cyanolepra was associated with warm wet winters, little monthly temperature variation, and silty soils (AUC $=0.86, p=0.01$ ). $R$. diploschistidina was associated with warm, dry sites with low percent sand (AUC $=0.88, p=0.01) . T$. sancti-jacobi was associated with warm dry sites with silty or rocky soil (AUC $=0.95$, $p=0.01)$. 
Urban, agricultural, and wind farm development coincided with sites having the combination of soil and climate characteristics that would otherwise be especially favorable for these uncommon soil crust lichens (Figures 2, 3). Habitats remaining in natural vegetation or in poor or marginal wind farm potential categories were generally of poorer quality for all four modeled lichen species. Where agriculture or development has already occurred, the habitat for all species would be better at marginal, fair, and good wind farm potentials than at poor wind farm sites. At natural vegetation sites, the association between habitat quality and wind farm potential was less pronounced. For all species, sites with natural vegetation and fair wind farm potential were more favorable than those with marginal or poor potential; however, sites with good wind farm potential were not significantly better habitat than those with fair wind farm potential.

A large proportion of the favorable habitats for the four focal lichens were affected by development or agriculture. Twenty-eight, 32, 31, and $42 \%$ of habitats favorable for A. schleicheri, F. cyanolepra, R. diploschis tidina, and T. sancti-jacobi, respectively, were currently in agriculture or developed land; 7, 5, 14, and 10\% were in fair or good wind potential sites with natural vegetation (Table 1). For each species we rejected the null hypothesis that habitat favorability was independent of wind farm potential (Table $2, \chi_{3}^{2}=138.6,67.5$, 103.7, 338.7, for A. schleicheri, F. cyanolepra, R. diploschis tidina, T. sancti-jacobi, respectively; $p<0.001$ for all species).

\section{Discussion}

Acarospora schleicheri, Fuscopannaria cyanolepra, Rhizo carpon diploschistidina, and Texosporium sancti-jacobi are likely to be uncommon in part because of their association with habitats that are favorable for urban, agricultural, and wind development: approximately onethird to one-half of favorable habitat for each of these lichens in our study area has already been affected or is at risk of development. Agriculture and urban development are highly unlikely to support biotic soil crust

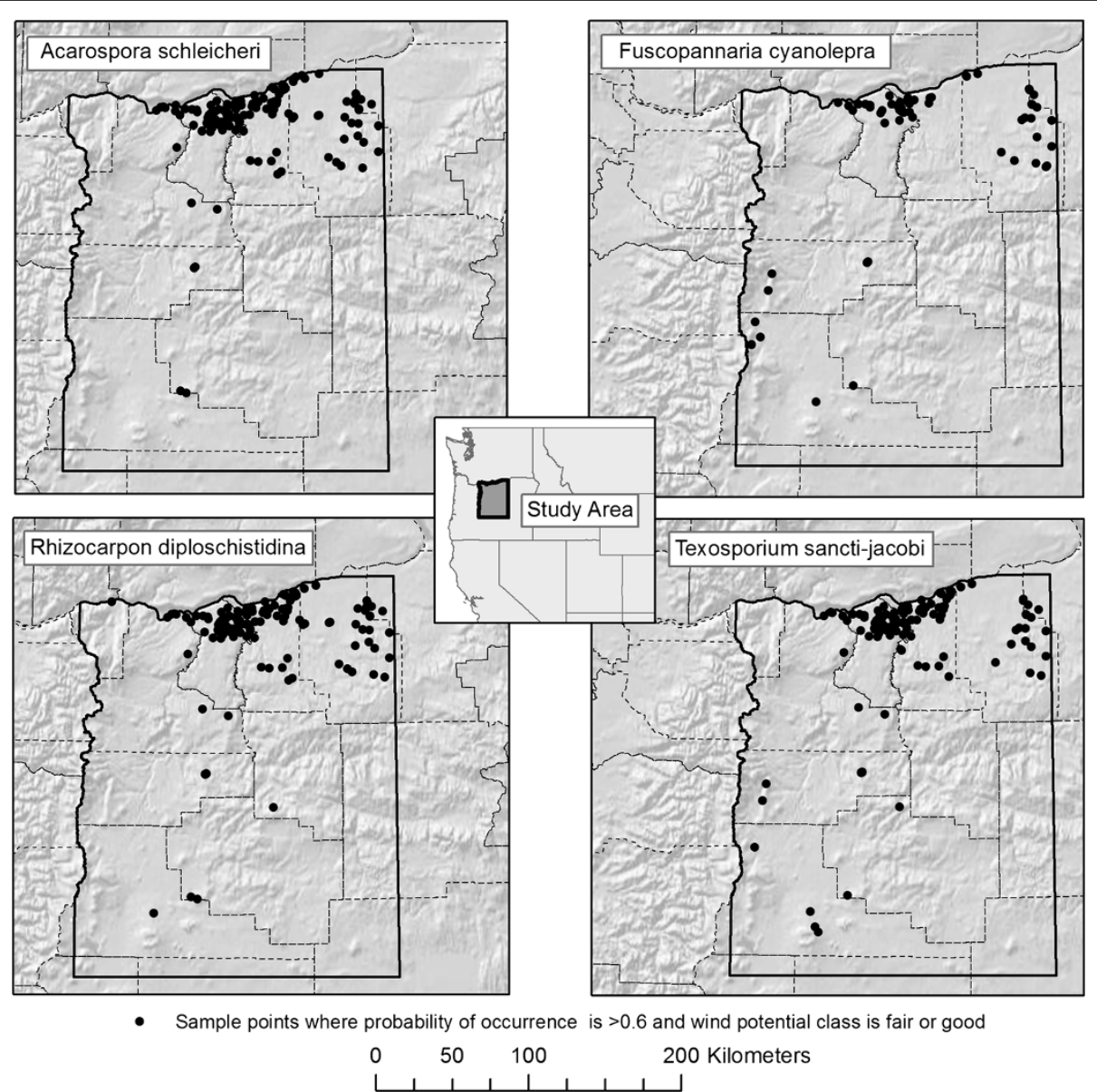

Figure 2 Map of favorable habitat with fair or good wind potential. Randomly selected points for which predicted probability of occurrence exceeded 0.6 and wind potential was categorized as fair or good. 


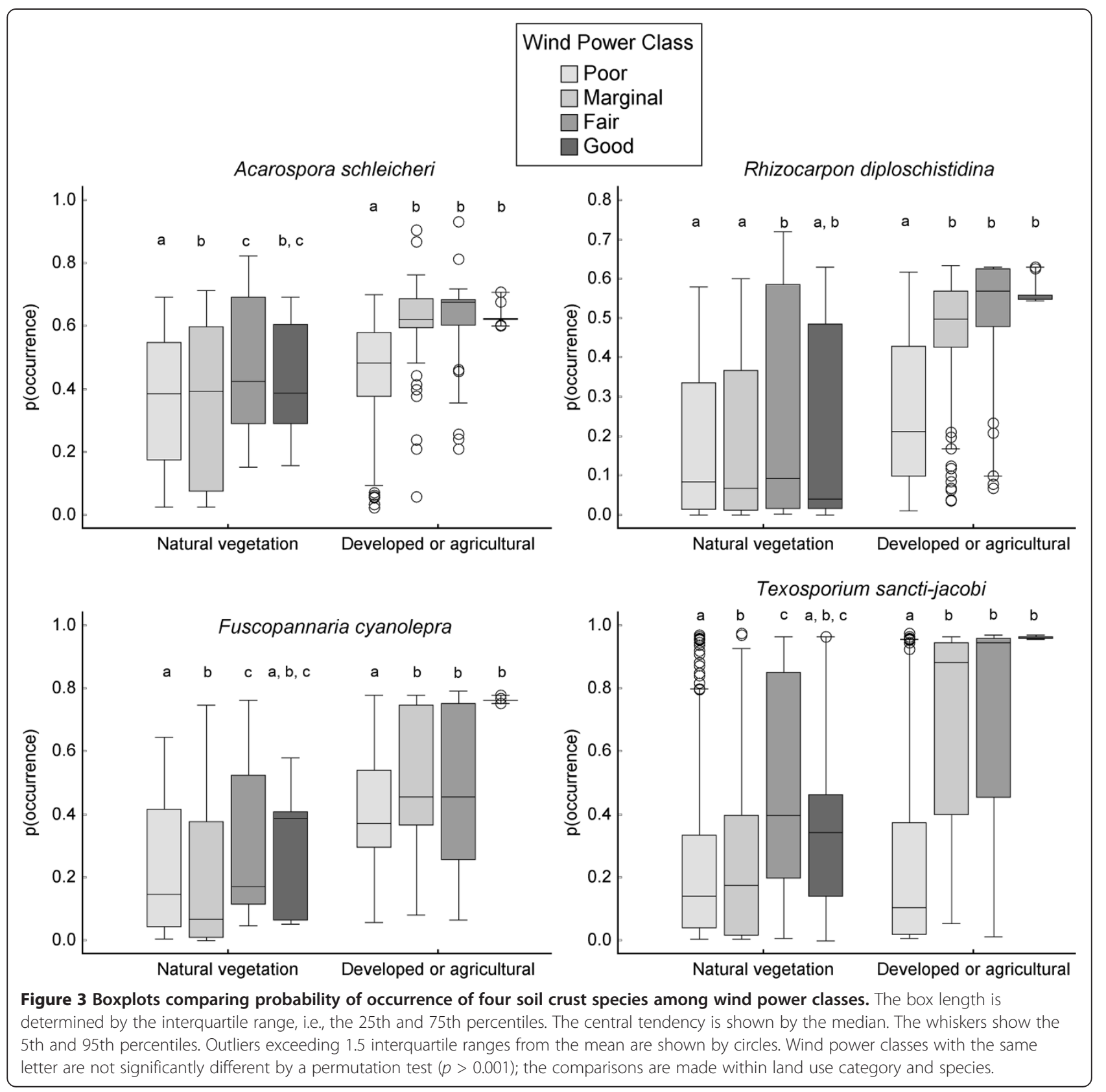

Table 1 Percent of favorable habitat for four uncommon soil crust lichens affected by development and natural sites in fair or good wind farm potential categories

\begin{tabular}{|c|c|c|c|c|}
\hline Species & $\begin{array}{c}\% \text { developed or in } \\
\text { agriculture }\end{array}$ & $\mathrm{Cl}$ & $\begin{array}{l}\% \text { in fair or good wind } \\
\text { farm potential }\end{array}$ & $\mathrm{Cl}$ \\
\hline Acarospora schleicheri & 28 & $25-31$ & 7 & $5-9$ \\
\hline Fuscopannaria cyanolepra & 32 & $27-37$ & 5 & $3-7$ \\
\hline Rhizocarpon diploschistidina & 31 & $25-37$ & 14 & $10-19$ \\
\hline Texosporium sancti-jacobi & 42 & $38-47$ & 10 & $7-13$ \\
\hline
\end{tabular}

The $95 \%$ confidence intervals $(\mathrm{Cl})$ are based on a normal approximation of the binomial distribution, with sample size equal to the number of points falling in favorable habitats. 
Table 2 Number of points with predicted lichen probabilities of occurrence in each land use class for four uncommon soil crust lichen species

\begin{tabular}{|c|c|c|c|c|c|}
\hline & & \multicolumn{4}{|c|}{ Wind farm potential } \\
\hline & & Poor & Marginal & Fair & Good \\
\hline \multicolumn{6}{|l|}{ Acarospora schleicheri } \\
\hline \multirow[t]{2}{*}{$p$ (occurrence) $<0.60$} & Natural vegetation & 1,458 & 660 & 83 & 8 \\
\hline & Developed or agriculture & 150 & 84 & 15 & 1 \\
\hline \multirow[t]{2}{*}{$p$ (occurrence) $>0.60$} & Natural vegetation & 362 & 192 & $58^{\#}$ & $3^{\#}$ \\
\hline & Developed or agriculture & $33^{*}$ & $152^{*}$ & $45^{*}$ & $10^{*}$ \\
\hline \multicolumn{6}{|c|}{ Fuscopannaria cyanolepra } \\
\hline \multirow[t]{2}{*}{$p$ (occurrence) $<0.60$} & Natural vegetation & 1,610 & 711 & 93 & 9 \\
\hline & Developed or agriculture & 141 & 107 & 22 & 0 \\
\hline \multirow[t]{2}{*}{$p$ (occurrence) $>0.60$} & Natural vegetation & 142 & 82 & $18^{\#}$ & $0^{\#}$ \\
\hline & Developed or agriculture & $27^{*}$ & $62^{*}$ & $15^{*}$ & $9^{*}$ \\
\hline \multicolumn{6}{|c|}{ Rhizocarpon diploschistidina } \\
\hline \multirow[t]{2}{*}{$p$ (occurrence) $<0.60$} & Natural vegetation & 1,746 & 818 & 108 & 11 \\
\hline & Developed or agriculture & 174 & 183 & 43 & 9 \\
\hline \multirow[t]{2}{*}{$p$ (occurrence) $>0.60$} & Natural vegetation & 84 & 43 & $32^{\#}$ & $1^{\#}$ \\
\hline & Developed or agriculture & $12^{*}$ & $43^{*}$ & $15^{*}$ & $2^{*}$ \\
\hline \multicolumn{6}{|c|}{ Texosporium sancti-jacobi } \\
\hline \multirow[t]{2}{*}{$p$ (occurrence) $<0.60$} & Natural vegetation & 1,603 & 686 & 83 & 10 \\
\hline & Developed or agriculture & 151 & 95 & 19 & 0 \\
\hline \multirow[t]{2}{*}{$p$ (occurrence) $>0.60$} & Natural vegetation & 110 & 141 & $51^{\#}$ & $2^{\#}$ \\
\hline & Developed or agriculture & $35^{*}$ & $138^{*}$ & $40^{*}$ & $11^{*}$ \\
\hline
\end{tabular}

Favorable habitat that has already been developed or is in agriculture is indicated by ${ }^{*}$. Favorable natural habitat with fair or good wind farm potential is indicated by ; some of these sites currently support wind farms and others do not.

communities because of the intensive soil disturbance associated with these land uses. More subtle surface disturbances such as off-road vehicles (Belnap 2002) and livestock grazing (Ponzetti and McCune 2001) also negatively affect biotic soil crust communities in the region and likely play a role in reducing populations on wildlands. However, little is known about how wind farms will affect these organisms. How could the development of the 5 and $14 \%$ of favorable habitats in areas of fair or good wind farm potential benefit or harm uncommon soil crust lichens?

Because favorable habitats with silty soils and less continental climates have already been disproportionately affected by development and agriculture, remaining populations in natural vegetation are especially important. As wind farms are more likely to be placed in remaining favorable habitat, surveys are likely to reveal unknown populations and may provide valuable better estimates of rarity and a clearer understanding of habitat associations. Wind farm sites are typically surveyed by botanists prior to permitting; inclusion of these conspicuous soil crusts in their target species lists could identify at-risk populations and allow permitting agencies the opportunity to suggest mitigation measures such as grazing exclosures, alternative road placement, or other ways to minimize soil disturbance.

Although we focus on habitats for four uncommon soil crust species, these communities are composed of a rich assemblage of species, many of which are cryptic or too rare for habitat modeling. Subtle and rare species often occur in habitats with well-developed conspicuous crusts (Root et al. 2011). By protecting late-successional soil crusts that are specifically associated with at-risk habitats, such as $A$. schleicheri and $R$. diploschistidina, we are likely to protect a suite of other uncommon soil crust lichen, bryophyte, fungi, algal, and cyanobacterial species. Many of these uncommon soil crust taxa are poorly known; as surveyors learn more about their habitats, they may recommend more species for state and federal rare plant lists.

Plans for wind farm development on federally owned land estimate $5-10 \%$ surface disturbance by turbines and access road development (BLM 2005). Land use under the turbines is likely to differ depending on ownership. On wildlands, wind development has the opportunity to protect $90-95 \%$ of the land as native vegetation and support flourishing soil crust populations that would be substantially more threatened by some other land 
use, such as intensive grazing or agriculture. If wind farms are fenced and not grazed, they could provide valuable refugia for soil crusts.

Other construction considerations could ensure that remaining habitat is preserved. For example, minimizing the introduction of weedy annual grasses may encourage recovery of soil crust communities where soil is disturbed. Furthermore, focusing ground disturbance in areas that are already affected by exotic species may spare more valuable native habitat. As plans for development unfold, planners should interpret any soil disturbance to have negative impacts on soil crusts, even if there are subsequent restoration efforts. Many areas that are disturbed in construction are restored by planting crested wheatgrass (Agropyron cristatum) or native bunchgrasses such as Poa sandbergii. Where vascular vegetation is planted, we cannot assume that the site has been restored to native conditions because soil crusts are estimated to require approximately 125 years to re-establish late successional communities following disturbance in the northern Great Basin (Belnap et al. 2001).

Wildfire often has a negative effect on soil crust communities (Ponzetti et al. 2007); it is unclear how wind farm development will affect fire regimes. Although shrub-steppe habitats naturally experience wildfires, the introduction of exotic grasses has increased fire frequency and extent in this region (Whisenant 1990). Increased human access through the new roads could spark a greater number of human-caused fires or improve fire suppression efforts. Monitoring changes in fire regimes associated with wind farms may help managers interpret their effects on native vegetation.

\section{Conclusions}

Organisms in shrub-steppe habitats respond to a variety of factors including soil texture and climate variability. Soil crust communities incorporating uncommon lichen species are associated with finetextured soils along the rivers of the Columbia Basin. The most favorable habitat for these lichens coincides with productive agricultural and wind farm sites in the region. Much potential soil crust lichen habitat has been lost to urban and agricultural development. Although more habitat is at risk in potential wind farm sites, we have the opportunity to encourage the development of this alternative energy in a way that conserves uncommon soil crust lichens. We suggest surveying for four conspicuous soil crust species before construction and planning new facilities such that remaining habitat can be preserved in a way that is compatible with wind development.
Competing interests

The authors declare that they have no competing interests.

\section{Authors' contributions}

$\mathrm{BM}$ and HTR conceived of and designed the project. HTR conducted the fieldwork, performed some statistical analyses, and drafted the manuscript. MM assembled GIS data, performed GIS analyses, and assisted with manuscript preparation. BM performed statistical analyses and assisted with manuscript preparation. All authors read and approved the final manuscript.

\section{Acknowledgements}

Sampling and analysis of soil crust lichen data were supported by Kelli Van Norman through the Region 6 Forest Service and OR/WA Bureau of Land Management Interagency Special Status/Sensitive Species Program. Jesse Miller, supported through the Bureau of Land Management and Chicago Botanical Garden, assisted with fieldwork. This manuscript was improved by discussions with Rick Demmer and Olivia Duren. The manuscript was improved by comments from Matthew Bowker and one anonymous reviewer.

\section{Author details}

${ }^{1}$ Department of Botany and Plant Pathology, Oregon State University, 2082 Cordley Hall, Corvallis, OR 97330, USA. ${ }^{2}$ Institute for Natural Resources, Oregon State University, 210 Strand Agricultural Hall, Corvallis, OR 97331, USA. ${ }^{3}$ Current address: Department of Forest Ecosystems and Society, Oregon State University, 321 Richardson Hall, Corvallis, OR 97331, USA.

Received: 18 October 2012 Accepted: 19 April 2013

Published: 15 May 2013

\section{References}

Baerwald EF, Barclay RWR (2009) Geographic variation in activity and fatality of migratory bats at wind energy facilities. J Mammal 90:1341-1349

Belnap J (2002) Impacts of off-road vehicles on nitrogen cycles in biological soil crusts: resistance in different U.S. deserts. J Arid Environ 52:155-165

Belnap J, Kaltenecker JH, Rosentreter R, Williams J, Leonard S, Eldridge D (2001) Biological soil crusts: ecology and management, Technical Reference 1730-2. USDI, Bureau of Land Management, U.S. Government Printing Office, Denver, $\mathrm{CO}$

Beymer RJ, Klopatek JM (1991) Potential contribution of carbon by microphytic crusts in pinyon-juniper woodlands. Arid Soil Res Rehabil 5:187-198

Bowman AW, Azzalini A (1997) Applied smoothing techniques for data analysis. Clarendon, Oxford, UK

BLM (Bureau of Land Management) (2005) Final programmatic environmental impact statement on wind energy development on BLM administered land in the western United States. US Department of the Interior, BLM, Washington, DC, http://windeis.anl.gov. Accessed September 2012

Clarke SE, Bryce SA (1997) Hierarchical subdivisions of the Columbia Plateau and Blue Mountains Ecoregions, Oregon and Washington. General Technical Report PNW-GTR-395. US Department of Agriculture, Forest Service, Pacific Northwest Research Station, Portland, OR, ftp://ftp.epa.gov/wed/ecoregions/. Accessed August 2009

Crawford JA, Olson RA, West NE, Mosley JC, Schroeder MA, Whitson TD, Miller RF, Gregg MA, Boyd CS (2004) Ecology and management of sage-grouse and sage-grouse habitat. Rangel Ecol Manage 57:2-19

Daly C, Halbleib M, Smith Jl, Gibson WP, Doggett MK, Taylor GH, Curtis J, Pasteris PP (2008) Physiographically sensitive mapping of climatological temperature and precipitation across the United States. Int J Climatol 27:935-969

Drewitt AL, Langston RHW (2006) Assessing the impacts of wind farms on birds. Ibis 148:29-42

Friedl T (1987) Thallus development and phycobionts of the parasitic lichen Diploschistes muscorum. Lichenologist 19:183-191

Harper KT, Marble JR (1988) A role for nonvascular plants in management of arid and semiarid rangelands. In: Tueller PT (ed) Vegetation science applications for rangeland analysis and management. Kluwer, Dordrecht, pp 135-170

Harper KT, Pendleton RL (1993) Cyanobacteria \& cyanolichens: can they enhance availability of essential minerals for higher plants? Great Basin Naturalist 53:59-72

Jones CG, Lawton JH, Shachak M (1997) Positive and negative effects of organisms as physical ecosystem engineers. Ecology 78:1946-1957 
Kaltenecker JH, Wicklow-Howard M, Pellant M (1999) Biological soil crusts: natural barriers to Bromus tectorum L. establishment in the northern Great Basin, USA. In: Eldridge D, Freudenberger D (eds) Proceedings of the VI International Rangeland Congress. Aitkenvale, Queensland, Australia, pp 109-111

Leys JF, Eldridge DJ (1998) Influence of cryptogamic crust disturbance to wind erosion on sand and loam in rangeland soils. Earth Surf Process Landforms 23:963-974

Lumbsch HT, Ahti T, Altermann S, De Paz GA, Aptroot A, Arup U, Pena AB, Bawingan PA, Benatti MN, Betancourt L, Björk CR, Boonpragob K, Brand M, Bungartz F, Cáceres MES, Candan M, Chaves JL, Clerc P, Common R, Coppins BJ, Crespo A, Dal-Forno M, Divakar PK, Duya MV, Elix JA, Elvebakk A, Fankhauser JD, Farkas E, Ferraro LI, Fischer E et al (2011) One hundred new species of lichenized fungi: a signature of undiscovered global biodiversity. Phytotaxa 18:1-127

Mazor G, Kidron GJ, Vanshank A, Abeliovich A (1996) The role of cyanobacterial exopolysaccharides in structuring desert microbial crusts. FEMS Microbiol Ecol 21:121-130

McCune B (2006) Non-parametric habitat models with automatic interactions. Journal of Vegetation Science 17:819-830

McCune B, Mefford MJ (2011a) HyperNiche. Version 2.10. MjM Software. , Gleneden Beach, OR

McCune B, Mefford MJ (2011b) PC-ORD. Multivariate analysis of ecological data. Version 6.08. MjM Software., Gleneden Beach, OR

McCune B, Rosentreter R (1992) Texosporium sancti-jacobi, a rare western North American lichen. Bryologist 95:329-333

McCune B, Rosentreter R (2007) Biotic soil crust lichens of the Columbia Basin. Monogr N Am Lichenol 1:1-105

Mielke PW Jr, Berry KJ (2001) Permutation methods: a distance function approach. Springer Verlag, New York, 344 pp

Mitchell C, Agrawal A, Bever J, Gilbert G, Hufbauer R, Klironomos J, Maron J, Morris W, Parker I, Power A, Seabloom A, Torchin M, Vázquez D (2006) Biotic interactions and plant invasions. Ecol Lett 9:726-740

National Renewable Energy Laboratory (2002) TrueWindSolutions, PNW_50m_wind_resource [shapefile geospatial data], coverage: Pacific Northwest, United States of America., updated April 2002. http://www.nrel. gov/gis/data_wind.html. Accessed August 2012

NRCS (Natural Resources Conservation Service) (2010) United States Department of Agriculture, Soil Survey Geographic Database for Oregon. http://soildatamart.nrcs.usda.gov. Accessed December 2010

NPCC (Northwest Power and Conservation Council) (2010) Sixth Northwest conservation and electric power plan. Council document 2010-09. http://www.nwcouncil.org/. Accessed September 2012

ORBIC (Oregon Biodiversity Information Center) (2010a) Rare, threatened and endangered species of Oregon. Portland State University, Portland, OR, Institute for Natural Resources

ORBIC (Oregon Biodiversity Information Center) (2010b) Ecological system life form data. http://www.oregon.gov/DAS/CIO/GEO/pages/alphalist.aspx\#e. Accessed April 2011

Ponzetti JM, McCune B (2001) Biotic soil crusts of Oregon's steppe: community composition in relation to soil chemistry, climate, and livestock activity. Bryologist 110:706-722

Ponzetti JM, McCune B, Pyke D (2007) Biotic soil crusts in relation to topography, cheatgrass and fire in the Columbia Basin, Washington. Bryologist 110 (4):706-722

Root HT, McCune B (2012) Regional patterns of biological soil crust lichen species composition related to vegetation, soils, and climate in Oregon, USA. J Arid Environ 79:93-100

Root HT, Miller JED, McCune B (2011) Biotic soil crust lichen diversity and conservation in shrub-steppe habitats of Oregon and Washington. Bryologist 114(4):796-812

Rosentreter R (2004) Sagebrush identification, ecology, and palatability relative to sage-grouse. In: Shaw NL, Monsen SB, Pellant M (eds) Sagegrouse habitat restoration symposium proceedings; 2001 June 4-7; Boise, ID. Proceedings RMRS-P-000. Department of Agriculture, Forest Service, Rocky Mountain Research Station, Ft. Collins, CO

Rychert RJ, Skujins J, Sorensen D, Porchella D (1978) Nitrogen fixation by lichens and free-living microorganisms in deserts. In: West NE, Skujins J (eds) Nitrogen in desert ecosystems. Doden, Hutchinson \& Ross, Stroudsburg, PA, pp 20-30
Tibell T, van Hofsten A (1968) Spore evolution of the lichen Texosporium sancti-jacobi (= Cyphelium sancti-jacobi). Mycologia 60:553-558

Whisenant SG (1990) Changing fire frequencies on Idaho's Snake River plains: ecological and management implications. In: McArthur ED (ed) Proceedings of the symposium on cheatgrass invasion, shrub die-off, and other aspects of shrub biology and management. General Technical Report INT-270. US Department of Agriculture, Forest Service, Intermountain Research Station, Ogden, UT, pp 4-10

doi:10.1186/2192-1709-2-10

Cite this article as: Root et al:: Wind farm potential is higher in prime habitat for uncommon soil crust lichens. Ecological Processes 2013 2:10.

\section{Submit your manuscript to a SpringerOpen ${ }^{\circ}$ journal and benefit from:}

- Convenient online submission

Rigorous peer review

- Immediate publication on acceptance

- Open access: articles freely available online

- High visibility within the field

- Retaining the copyright to your article

Submit your next manuscript at $>$ springeropen.com 